\title{
Why typos in DNA may help to fuel atherogenesis and inflammation prior to heart attacks, ischemic heart disease, and sudden-death ischemic heart disease: roles of unrecognized ionized hypomagnesemia and epigenetics
}

\section{Introduction}

A considerable number of clinical and experimental studies have taken place around the globe suggesting that diverse chemicals and mutagens can produce genotoxic effects in multiple tissues and cells. ${ }^{1,2}$ Genotoxicity denotes, in genetics, a destructive effect(s) on a cell's genetic material (i.e., DNA, RNA), thus potentially altering cell integrity functions, and phenotypes.

Genotoxins are, therefore, mutagens. Several of these well-known genotoxins include radiation of diverse types and chemicals known to damage DNA. The final result of genotoxins induce modifications of gene expression. Even though numerous advances are being made every day about genotoxins, little is known about the potential mechanisms involved in exactly how genotoxins induce lesions in DNA and how these toxic agents result in chromosomal aberrations.

We have provided putative evidence that magnesium $(\mathrm{Mg})$ deficient environments can behave like genotoxins on cardiovascular tissues and cells. ${ }^{3-5}$ We continue this line of thought, below, for believing Mgdeficient environments can result in inflammatory lesions which can result in atherogenesis, thus leading to heart attacks, ischemic heart disease (IHD), cardiac failure (CF), sudden-death ischemic heart disease (SDIHD), and strokes.

\section{DNA typos and disease etiology}

When any cell divides, its six billion letters of DNA are copied with each new copy going to each daughter cell. During this duplication process, it is now known that so-called "typos" inevitably occur, and a cell's DNA-proofreading mechanism (s) "usually catch and correct" these typos. ${ }^{6}$ But, sometimes this "catch-up and correct mechanism" fails, and if this occurs in certain critical regions of the genome, this can shuttle a cell into a new form of growth and differentiation. ${ }^{6}$ Using this hypothesis, a team led by Tomasetti, Liu and Vogelstein, in 2017, with mathematical analyses, suggested "typos in DNA "were found in 32 different cancer types. They attributed these "typos" either to a heredity environment or "random DNA copying errors. Tomasetti et al calculated that $66 \%$ of cancer mutations occur from DNA copying errors. ${ }^{6}$ Most of the others occurred via environmental factors according to their calculations.

Mg deficiency results in alterations in cardiovascular tissue and cellular telomerases, DNA, micro-rnas, inflammatory lesions and atherogenesis

Interestingly, we have recently reported that rats'cardiovascular tissues and cells, extirpated from rats fed $\mathrm{Mg}$ deficient
Volume 5 Issue 3 - 2020

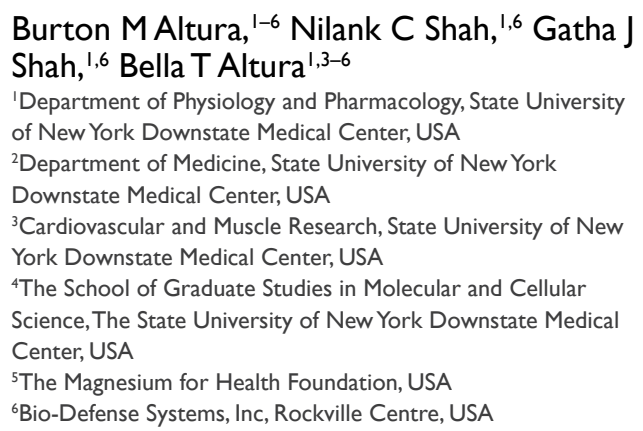

Correspondence: Dr Burton M Altura, Department of Physiology and Pharmacology, School of Graduate Studies in Molecular and Cellular Science, SUNY Downstate Medical Center, Brooklyn, New York, USA, Tel 718-270-2194, Fax 7|8-270-3103, Email burton.altua@downstate.edu

Received: July 24, 2020 | Published: August 20, 2020

diets,demonstrate a down-regulation of telomerases, oxidation and fragmentation of DNA, lipid peroxidation, alteration of micro-RNAs, methylation of DNA, and alteration in histones..$^{7-12}$ Taken together, such modifications in DNA, RNA, and micro-RNAs could easily account for development of inflammatory lesions, atherogenesis, and arterial plaques seen in our experimental rats, rabbits and guinea-pigs.

\section{Disturbances in diet and $\mathrm{Mg}$ intake linked to development of inflammatory lesions and atherogenesis}

Dietary alterations are known to cause lipid deposition and accelerate the growth and transformation of smooth muscle and endothelial cells in the vascular walls of blood vessels and promote vascular and cardiac dysfunctions of diverse types, i.e., atherosclerosis, heart rhythm disturbances, decreased force of ventricular and atrial contractility, increases in arterial blood pressure, diminished venous return to the heart, cardiac tamponade, hypertension, strokes, SDIHD, myocardial infarctions, etc. ${ }^{13-15}$

Several epidemiologic studies in North America and Europe, and The UK have shown that people consuming Western -type diets are quite low in $\mathrm{Mg}$ intake (i.e., $30-65 \%$ of the RDA for $\mathrm{Mg}$ ) ${ }^{16-18}$ Most 
of The North Americans are consuming only about $185-235 \mathrm{mg} \mathrm{Mg} /$ day. ${ }^{16-18}$ In 1900, Most diets in the USA contained about 450-550 $\mathrm{mg} \mathrm{Mg}$ /day. Low $\mathrm{Mg}$ content of drinking water, found in areas of soft-water and $\mathrm{Mg}$-poor soil, is associated with high incidences of atherosclerosis, IHD, coronary vasospasm (i.e., Prinzmetal spasm), hypertension, and SDIHD. ${ }^{17,19-26}$ Are these facts coincidences?

Both animal and human studies have demonstrated an inverse relationship between dietary intake of Mg and atherosclerosis. ${ }^{3-5,17,19,22-31}$ The myocardial level of $\mathrm{Mg}$ has consistently been observed to be lower in subjects dying from IHD and SDIHD in soft-water areas than those in hard-water areas. ${ }^{17,19-25,32} \mathrm{Mg}$ plays critical roles in more that 500 enzymatic reactions in the body, ${ }^{33}$ and is required for all energygenerating reactions and oxidative phosphorylation. , $33,34^{2}$

Approximately, 50 years ago, two of us demonstrated that $\mathrm{Mg}^{2+}$ behaves as a $\mathrm{Ca}^{2+}$ channel blocker at vascular smooth muscle membranes; ${ }^{35-39}$ later we showed that $\mathrm{Mg}^{2+}$ modulated $\mathrm{Ca}^{2+}$ currents in capillary endothelial membranes ${ }^{40,41}$ and regulation of intracellular $\mathrm{Ca}^{2+} \cdot{ }^{37-39} \mathrm{We}$ also showed that $\mathrm{Mg}$ plays a role as a "natural statin" in the body, as it can lower blood levels of cholesterol and triglycerides ${ }^{10,17,27}$ as well as a powerful vasodilator in the microcirculation, ${ }^{42-45}$ and a cardiac relaxant. ${ }^{7,46-49}$

Hypermagnesemic diets have been shown to ameliorate hypertension and atherogenesis. ${ }^{26,27,42,45,50,51}$ Using sensitive and newlydesigned specific $\mathrm{Mg}^{2+}$-electrodes, our laboratories have demonstrated that many patients with drug-resistant hypertension, IHD, early cardiac failure, atrial fibrillation, alcoholic heart disease, diabetes types 1 and 2, pregnant women with preeclampsia-eclampsia, renal-induced vascular damage(associated with elevated serum cholesterol), loss of blood volume, headaches, and atherosclerosis exhibit significant reductions in serum/plasma/whole blood ionized $\mathrm{Mg}$ as well as intracellular free Mg. ${ }^{5,17,22,29,52-106}$ Moreover, our labs have shown that dietary $\mathrm{Mg}$ deficiency, in rats and rabbits, causes vascular remodeling concomitant with atherogenesis (i.e., arteriolar wall hypertrophy and alterations in the matrices of the vascular walls) along with elevations in systolic (SBP), diastolic and pulsepressure(PP). ${ }^{22,52,75,78,91,96,100,105,106}$ These findings could be considered the end results of genotoxicity. We have very recently presented new clinical molecular/biochemical data and a rationale for why and how $\mathrm{Mg}$ deficiency in type 2 diabetes induces elevations in both SBP and PP, as well as high risks for IHD and SDIHD, particularly in men over the age of $60 . .^{105,106}$

Several of our experimental results, found in diabetic and drugresistant hypertensive subjects, have recently been observed to endup in an acceleration of the aging process. ${ }^{100,105,106}$ We firmly believe these latter genotoxic-epigenetic actions of $\mathrm{Mg}$ deficiency are also potentially the end result of low environmental levels of $\mathrm{Mg}$ in bodily fluids and dietary composition. Many of the pathophysiological and pathological molecular-biochemical alterations typically observed in tissues and cells,in the aging process, have been noted in aging cardiovascular tissues, in animals and patients, by our group and by several other groups. ${ }^{107,108}$ But, what are the specific mechanisms linked to $\mathrm{Mg}$ deficiency?

\section{Roles of proto-oncogenes, NF-kB, p53, DNA damage,} PKC isozymes, and epigenesis

\section{NF-kB and proto-oncogenes}

Atherogenesis is a complicated inflammatory process that involves activation, proliferation, and alterations in phenotypes (i.e., contractile smooth muscle cells change to non-contractile, secreting synthetic machines). ${ }^{13-15,109}$ with survival of diverse macrophages changing to monocytes which invade the endothelial cells in the arteriolar and arterial walls. ${ }^{109}$ In addition, in this evolving atherosclerotic process, NF-kB and the proto-oncogenes c-fos and c-jun must be activated. ${ }^{110-113}$ We have, indeed found in $\mathrm{Mg}$ deficient animals and humans that both NF-kB and the proto-oncogenes c-fos and c-jun are activated and expressed. . $^{4,9,17,28,75,78,91,100,104,114}$ In consonant with these molecular alterations, low $\mathrm{Mg}$ environments have been found, in our $\mathrm{Mg}$ deficient rats and rabbits, to promote proliferation and migration of diverse cell types needed for generation of atherogenesis. ${ }^{5,17,22,25,26,100,114}$ These genotoxic effects were found to result in release of cytokines and chemokines from primary cultured vascular smooth muscle and human endothelial cells by our group. ${ }^{17,75,77,78,100,101,106}$ molecules required for transformation, growth and differentiation of macrophages/monocytes, vascular muscle and endothelial cells in the evolving atherogenic process. ${ }^{11-13,109}$ Supplemental, elevated dietary levels of $\mathrm{Mg}$ ameliorate/inhibit the latter transformations, at least in experimental animals. ${ }^{25,26,100,101,106}$

\section{P53, DNA damage and epigenesis}

Another, important, critical molecular trigger in the evolving atherosclerotic process is activation of the tumor suppressor gene, p53, particularly in the advanced stages of atherosclerosis. ${ }^{115-117}$ DNAdamage is thought to be the trigger for activation of $\mathrm{p} 53 .{ }^{116}$ This latter event starts a sequence that regulates growth arrest, cell senescence, apoptosis and programmed cell death of the vascular smooth muscle cells. Using rabbits fed low-Mg-high cholesterol diets, we have reported, with histochemical techniques, plaques containing elevated levels of p53. ${ }^{118}$ Not surprisingly, using rats subjected to 21-days of $\mathrm{Mg}$ deficiency, we found that cardiovascular tissues and cells of these animals demonstrated 6-8x up-regulation of p53 along with growth arrest, cell senescence, apoptosis, and several forms of programmed CD (i.e.,apoptosis, necroptosis, pyroptosis, and ferroptosis). ${ }^{91,100,104,119-122}$ all events found in diverse forms of atherogenesis. ${ }^{13,14}$ As stated above, we have found considerable evidence to prove that $\mathrm{Mg}$ deficiency induces oxidation of DNA, ${ }^{11,12,91,100,123}$ fragmentation of DNA, histone alterations and methylation of the DNA all events clearly demonstrating epigenetic changes in the genomes of the $\mathrm{Mg}$ deficient cardiac and vascular smooth muscle cells.

\section{PKC isozymes and cell transformations}

PKC isozymes are well-known to regulate morphology, anchorage dependence, and cell tumorigenicity. ${ }^{124-129}$ Activation and overexpression of PKC isozymes, in low $\mathrm{Mg}^{2+}$ environments, would be consistent with a role for one or more PKC isozymes in transformation of phenotype of macrophages (to monocytes) and contractile vascular smooth muscle cells to a secreting phenotype (as we have observed in animals fed low $\mathrm{Mg}$ with high cholesterol diets). ${ }^{27}$ Using isolated aortic, cerebral and coronary vascular smooth muscle cells, we have found that low $\mathrm{Mg}^{2+}$ environments activate a number of biochemical pathways $^{130-133}$ to promote vasospasms including PKC isozymes, which if inhibited by specific antagonists, reduce markedly the contractile/vasospastic actions induced by low Mg. ${ }^{130-133}$

As predicted, exposure of rats and rabbits to low $\mathrm{Mg}$ diets, in our labs, resulted in a 6-10x upregulation of PKC isozymes (i.e., classical, novel, and atypical PKC types) In excised aortic, cerebral and coronary arterial muscle cells from these animals, PKC-zeta demonstrated the greatest upregulation. ${ }^{29,100,114,134}$ These findings were confirmed in examination of primary cultured aortic and cerebral vascular smooth muscle cells exposed to low $\mathrm{Mg}^{2+} \cdot{ }^{100,134}$ It is, thus, 
tempting to speculate that these up-regulations of several PKC isozymes probably play important roles in the cell transformation of macrophages (to monocytes) and contractile arterial smooth muscle cells to secreting machine cells in the inflammatory and atherogenic processes, in cardiac patients, drug-resistant hypertensive patients, and stroke patients, who have consumed low Mg diets for several decades.

The DNA alterations, such as oxidation, methylation and histone modifications, we have found in cardiac cells and arterial muscle cells ,excised from animals fed $\mathrm{Mg}$ deficient diets, along with up-regulation of proto-oncogenes, NF-kB, and several PKC isozymes, certainly would support our hypothesis that long-term dietary $\mathrm{Mg}$ deficiency could give rise to a genotoxic state, thus causing typos in DNA and atherogenesis leading to coronary arterial vasospasm, myocardial infarction, coronary arterial disease, ischemic heart disease, cardiac failure, stroke, and/or SDIHD.

\section{Conclusions}

In this presentation, we present a novel hypothesis indicating the probable critical role of $\mathrm{Mg}$ deficiency as a genotoxic agent in the development of inflammation-atherogenesis in the cardiovascular system to substantiate how Mg deficiency, over a period of time, triggers a series of molecular-biochemical -signaling events, stepby-step, that could account for growth and transformational changes in vascular smooth muscle cells, endothelial cells, macrophages and monocytes, all necessary for the inflammatory-atherogenic process. This report also reviews how deficient the North American, European, and The UK populations are at the present time, increasing the risks for ischemic heart disease, coronary artery disease, myocardial infarctions, atherosclerosis, sudden-death ischemic heart disease, and strokes.

\section{Acknowledgments}

Some of the original experimental and clinical studies mentioned in this review/hypothesis were supported, in part, by research grants from The National Institutes of Health (i.e., National Heart, Lung and Blood Institute; National Institute on Mental Health; National Institute on Drug Abuse; The National Institute on Alcoholism and Alcohol Abuse); NSF; and several unrestricted grants-in-aid from diverse pharmaceutical companies (i.e., The UpJohn Co.; Sandoz Pharmaceuticals; CIBA-GEIGY Corp; Pfizer Co.; The Bayer Pharmaceutical Co.; and Warner-Lambert Pharmaceuticals). We are grateful to a number of colleagues who aided us in our studies (i.e., J. Thaw, J. Hanley, A. Gebrewold, A. Carella, R.K. Gupta, L.M. Resnick, A.B. Kostellow, G.A. Morrill, R.L. Barbour, A. Zhang, T. Zheng, W. LI, X-C Jiang, N. Brautbar, F. Wu, M. Brust, J. Stempak, and S. Bloom).

\section{Conflicts of interest}

The author declares there are no conflicts of interest.

\section{References}

1. Kurelec B. The genotoxic disease syndrome. Marine Environmental Res. 1993;35(4):341-348.

2. Aiassa D. Genotoxic risk in human populations exposed to pesticides. In Larramendy ML, Soloneski S, editors. Genotoxicity. A Predictable Risk to Our Actual World. 2018
3. Altura BM, Shah NC, Li Z, et al. Short-term magnesium deficiency upregulates sphingomyelinase synthase and p53 in cardiovascular tissues and cells: relevance to de novo synthesis of ceramide. Am J Physiol Heart Circ Physiol. 2010;299(6):H2046-H2055.

4. Altura BM, Shah NC, Shah GJ, et al. Magnesium deficiency upregulates sphingomyelinases in cardiovascular tissues and cells: cross-talk among proto-oncogenes, $\mathrm{Mg}^{2+}, \mathrm{NF}-\mathrm{kB}$ and ceramide and their potential relationships to resistant hypertension, atherogenesis and cardiac failure. Int J Clin Exp Med. 2013;6(10):861-879.

5. Altura BM, Shah NC, Shah GJ, et al. Genotoxic effects of magnesium deficiency in the cardiovascular system and their relationships to cardiovascular diseases and atherogenesis. J Cardiovasc Dis \& Diagnosis. 2016;S1(1)

6. Tomasetti C, Li L, Vogelstein B. Stem cell divisions, somatic mutations, cancer etiology, and cancer. Science. 2017;355(6331):1330-1334.

7. Altura BM, Gebrewold A, Altura BT, et al. Magnesium depletion impairs carbohydrate and lipid metabolism and cardiac bioenergetics and raises myocardial calcium content in-vivo: relationship to etiology of cardiac disease. Biochem Mol Biol Int. 1996;40(6):1183-1190.

8. Wu F, Altura BT, Gao J, et al. Ferrylmyoglobin formation induced by acute magnesium deficiency in perfused rat heart causes cardiac failure. Biochim Biophys Acta. 1994;1225(2):158-164.

9. Altura BM, Gebrewold A, Zhang A, et al. Low extracellular magnesium induces lipid peroxidation and activation of nuclear factor- $\mathrm{kB}$ in canine cerebral vascular smooth muscle: possible relation to traumatic brain injury and strokes. Neurosci Lett. 2003;311(3):189-192.

10. Altura BM, Shah NC, Jiang XC, et al. Magnesium deficiency results in decreased levels of serum sphingomyelin, lipid peroxidation, and apoptosis in cardiovascular tissues. Am J Physiol Heart Circ Physiol. 2009;297:1186-1193.

11. Shah NC, Shah GJ, Li Z, et al. Short-term magnesium deficiency downregulates telomerase, upregulates neutral sphingomyelinase and induces oxidative DNA damage in cardiovascular tissues: relevance to atherogenesis, cardiovascular diseases and aging. Int J Clin Exp Med. 2014;7(3):497-514.

12. Altura BM, Shah NC, Shah GJ, et al. Magnesium deficiency results in oxidation and fragmentation of DNA, down regulation of telomerase activity, and ceramide release in cardiovascular tissues and cells: Potential relationship to atherogenesis, cardiovascular diseases and aging. $J$ Diabetol\&Vasc Dis Res. 2016;4(1e):1-5.

13. Lilly LS. Pathophysiology of Heart Disease. 2nd Ed. Saunders, Philadelphia. 2012.

14. Kumar V, Abbas AE, Aster JC. Robbins and Cotran Pathologic Basis of Disease. $9^{\text {th }}$ Ed. Elseveir-Saunders, Philadelphia. 2014

15. Majno G, Joris I. Cells, Tissues and Disease. $2^{\text {nd }}$ Ed. Oxford Univ Press, New York. 2004.

16. Seelig MS. Magnesium Deficiency in the Pathogenesis of Disease. Plenum, New York. 1980.

17. Altura BM, Altura BT. Magnesium and cardiovascular biology: an important link between cardiovascular risk factors and atherogenesis. Cell Mol Biol Res. 1995;41(5):347-359.

18. Mosfegh A, Goldman J, Abuja J, et al. What We Eat in America. NHANES 2005-2006: usual Nutrient Intakes from Food and Water Compared to 1997 Dietary Reference Intakes for Vitamin D, Calcium, Phosphorus, and Magnesium. U.S. Department of Agricultural Research, Wash, DC. 2009.

19. Crawford MD. Hardness of drinking water and cardiovascular disease. Proceedings of the Nutrition Society. 1972;31(3):347-357.

Citation: Altura BM, Shah NC, Shah GJ, et al.Why typos in DNA may help to fuel atherogenesis and inflammation prior to heart attacks, ischemic heart disease, and sudden-death ischemic heart disease: roles of unrecognized ionized hypomagnesemia and epigenetics. Int J Mol Biol Open Access. 2020;5(3): I I - I I 7. DOI: I0.15406/ijmboa.2020.05.00137 
20. Chipperfield B, Chipperfield JR. Relation of myocardial meta concentration to water hardness and death rates from ischaemic heart disease. Lancet. 1979;2(8145):709-712.

21. Nerbrand $\mathrm{CH}$, Swardsudd K, Ek J, et al. Cardiovascular mortality in seven counties in Sweden in relation to water hardness and geological settings: The project: Myocardial infarction in mid-Sweden. Eur Heart J. 1992;13(6):771-727.

22. Altura BM, Altura BT. Magnesium in cardiovascular biology. Sci Am Sci Med. 1995;2(3):28-37.

23. Marx A, Neutra RR. Magnesium in drinking water and ischemic heart disease. Epidemiol Rev. 1997;19(2):258-272.

24. Marier JR, Neri LC. Quantifying the role of magnesium in the relationship between human mortality/morbidity and water hardness. Magnesium. 1985;4(2-3):53-59.

25. Leary WP. Content of magnesium in drinking water and deaths from ischaemic heart disease in white South Africans. Magnesium. 1985;5(34):150-153.

26. Altura BT, Brust M, Gebrewold A, et al. Oral administration of magnesium aspartate HCL ameliorates experimental atherogenesis in rabbits. Magnesium: Exp Clin Res. 1987;6:150.

27. Altura BT, Brust M, Bloom S, et al. Magnesium dietary intake modulates blood lipid levels and atherogenesis. Proc Nat Acad Sci USA. 1990;87(5):1840-1844

28. Ouchi Y, Tabata RE, Stegiopoulos K, et al. Effect of dietary magnesium on development of atherosclerosis in cholesterol-fed rabbits. Arteriosclerosis. 1990;10(5):732-737.

29. Altura BM, Altura BT. Magnesium: forgotten mineral in cardiovascular biology and angiogenesis. In: New Perspectives in Magnesium Research. Springer, New York, 2007;239-260.

30. King JL, Miller RJ, Blue JP Jr, et al. Inadequate dietary magnesium intake increases atherosclerotic plaque development in rabbits. Nutr Res. 2009;29(5):545-549.

31. Dean C. The Magnesium Miracle. $3^{\text {rd }}$ Ed. Ballantine Books, New York. 2017.

32. Altura BM, Zhang A, Murakawa T, et al. Can hypomagnesemia put the squeeze on coronary arteries: An unappreciated factor in myocardial ischemia, heart attacks and sudden cardiac death. EC Orthopedics. 2019;10(7):572-581.

33. de Baaij JHF, Hoenderop JG, Bindels RJ. Magnesium in man: Implications for health and disease. Physiol Rev. 2015;95(1):1-46.

34. Pasternak K, Kocot J, Horecka A. Biochemistry of magnesium. J Elementol. 2010;15(3):601-616.

35. Altura BM, Altura BT. Influence of magnesium on drug-induced contractions and ion content in rabbit aorta. Am J Physiol. 1971;220(4):938-944.

36. Altura BM, Altura BT. Magnesium and contraction of arterial smooth muscle. Microvasc Res. 1974;7(2):145-155.

37. Altura BM, Altura BT. General anesthetics and magnesium ions as calcium antagonists. In: New Perspectives on Calcium Antagonists, Weiss GB, ed. Am Physiol Soc, Wash, DC, 1981;131-145.

38. Altura BM, Altura BT. Magnesium modulates calcium entry and contractility in vascular smooth muscle. In: Ohinishi T, Endo M, editors. Gated Calcium Transport Across Biological Membranes. Academic Press, New York, 1981;137-145.

39. Zhang A, Cheng TP-O, Altura BM. Magnesium regulates intracellular free ionized calcium. BiochimBiophys Acta. 1992;1134:25-29.
40. Delpiano M, Altura BM. Modulatory effect of extracellular $\mathrm{Mg}^{2+}$ ions on $\mathrm{K}^{+}$and $\mathrm{Ca}^{2+}$ currents of capillary endothelial cells from rat brain. FEBS Lett. 1996;394:335-339.

41. Delpiano M, Altura BM. Transmembrane currents in capillary endothelial cells are modulated by $\mathrm{Mg}^{2+}$ ions. Adv Exp Med Biol: frontiers in Arterial Chemoreception. 1997;410:115-118.

42. Altura BM. Magnesium and regulation of contractility of vascular smooth muscle. Adv in Microcirculation. 1982;11:77-113.

43. Nagai I, Gebrewold A, Altura BT, et al. Magnesium salts exert direct vasodilator effects on rat cremaster muscle microcirculation. Arch Intern Pharmacodyn. 1988;294:194-214

44. Nishio A, Gebrewold A, Altura BT, et al. Comparative effects of magnesium salts on reactivity of arterioles and venules to constrictor agents: An in situ study on microcirculation. J Pharmacol Exp Ther. 1988;246(3):859-865.

45. Nishio A, Gebrewold A, Altura BT, et al. Comparative vasodilator effects of magnesium salts on rat mesenteric arterioles and venules. Arch Intern Pharmacodyn. 1989;298:130-163.

46. Wu F, Zou LY, Altura BT, et al. Low extracellular magnesium results in cardiac failure in isolated perfused hearts. Magnes Trace Elem. 1992;10(5-6):364-373.

47. Barbour RL, Altura $\mathrm{BM}$, Reiner $\mathrm{SD}$, et al. Influence of $\mathrm{Mg}^{2+}$ on cardiac performance, intracellular free $\mathrm{Mg}^{2+}$ and $\mathrm{pH}$ in perfused hearts as assessed with ${ }^{31}$ P-NMR spectroscopy. Magnes Trace Elem. 1992;10(2-4):99-116.

48. Altura BM, Barbour RL, Dowd TL, et al. Low extracellular magnesium induces intracellular free $\mathrm{Mg}^{2+}$ deficits, ischemia, depletion of high-energy phosphates and cardiac failure in intact working rat hearts: $\mathrm{A}{ }^{31} \mathrm{P}-\mathrm{NMr}$ study. Biochim Biophys Acta. 1992;1182(3):328-332.

49. Friedman HS, Nguyen Th, Mokraoui M, et al. Effects of magnesium chloride on cardiovascular hemodynamics in the neutrally intact dog. $J$ Pharmacol Exp Ther. 1987;243(1):125-130.

50. DycknerP, Wester PO. Effect of magnesium on blood pressure. Br Med J Clin Res. 1983;286(6381):1847-1849.

51. Kass L. Effect of magnesium supplementation on blood pressure: a metaanalysis. Eur J Clin Nutr. 2011;66(4):411-418.

52. Altura BM, Altura BT. Role of magnesium in pathogenesis of high blood pressure: relationship to itsactions on cardiac and vascular smooth Muscle. In: Laragh JH, Brenner BM, editors. Hypertension: Pathophysiology, Diagnosis, and Management. Raven Press, New York, 1990;1003-1025.

53. Altura BT, Shirey T, Young CC, et al. A new method for the rapid determination of ionized $\mathrm{Mg}^{2+}$ in whole blood, serum and plasma. Methods and Find in Exp \& Clin Pharmacol. 1992;14(4):297-304.

54. Altura BT, Altura BM. Measurement of ionized magnesium in whole blood, plasma and serum with a new ion-selective electrode in healthy and diseased human subjects. Magnes Trace Elem. 1992;10(2-4):90-98.

55. Altura BT, Shirey TL, Young CC, et al. Characterization and studies of a new ion selective electrode for free extracellular magnesium ions in whole blood, plasma and serum. In: D'Orazio P, Burritt MF, editors. Electrolytes, Blood Gases and Other critical Analytes: The Patient, the Measurement, and the Government, vol 14, Electrolyte/Blood Gas Division AAcc, . Omni Press, WI, 152-173.

56. Mauskop A, Altura BT, Cracco RQ, et al. Serum ionized magnesium levels in patients with tension-type headaches. In: Olesen J, Schenen J, editors. Tension-type Headache: Classfication, Mechanisms and Treatment, Raven Press, New York, 1993;137-140.

57. Handwerker SM, Altura BT, Royo B, et al. Ionized magnesium and calcium levels in umbilical cord blood of pregnant women with transient hypertension during labor. Am J Hypertens. 1993;6(1):542-545. 
58. Markell MS, Altura BT, Barbour RL, et al. Ionized and total magnesium levels in cyclosporin-treated renal transplant recipients: relationship with cholesterol and cyclosporin. Clin Sci. 1993;85(3):315-318.

59. Markell MS, Altura BT, Sam Y, et al. Deficiency of serum ionized magnesium in patients receiving hemodialysis or peritoneal dialysis. ASAIO J. 1993;39:M801-M804.

60. Resnick LM, Altura BT, Gupta RK, et al. Intracellular and extracellular magnesium depletion in type 2 diabetes(non-insulin-dependent) diabetes mellitus. Diabetologia. 1993;36(8):767-770.

61. Altura BT, Shirey TL, Young CC, et al. Characterization of a new ion selective electrode for ionized magnesium in whole blood, plasma, serum and aqueous samples. Scand J Clin Lab Invest. 1994;54(suppl 217):21-36.

62. Altura BT, Altura BM. A method for distinguishing ionized, complexed and protein-bound $\mathrm{Mg}$ in normal and diseased subjects. Scand J Clin Lab Invest. 1994;54(suppl 217):83-88.

63. Altura BT, Burack J, Cracco RQ, et al. Clinical studies with the NOVA ISE for $\mathrm{Mg}^{2+}$. Scand J Clin Lab Invest Suppl. 1994;217:53-67.

64. Mauskop A, Altura BT, Cracco RQ, et al. Chronic daily headache-one disease or two? Diagnostic role of serum ionized magnesium. Cephalagia. 1994;14(1):24-28.

65. Memon ZI, Altura BT, Benjamin JL, et al. Predictive value of serum ionized but not total magnesium levels in head injuries. Scand J Clin Lab Invest. 1995;55(8):671-677.

66. Handwerker SM, Altura BT, Royo B, et al. Ionized serum magnesium and potassium levels in pregnant women with preeclampsia and eclampsia. $J$ Reprod Med. 1995;40(3):201-208.

67. Mauskop A, Altura BT, Cracco RQ, et al. Intravenous magnesium sulfate relieves migraine attacks in patients with low serum ionized magnesium levels: A pilot study. Clin Sci. 1995;89(6):633-636.

68. Bardicef M, Bardicef O, Sorokin Y, et al. Extracellular and intracellular magnesium depletion in pregnant and gestational diabetes. $\mathrm{Am}$ ObstetGynecol. 1995;172:1009-1013.

69. Handwerker SM, Altura BT, Jones KY, et al. Maternal-fetal transfer of ionized serum magnesium during stress of labor and delivery. $\mathrm{J} \mathrm{Am} \mathrm{Coll}$ Nutr. 1995;14(4):376-381.

70. Fogh Andersen N, Altura BM, Altura BT, et al. Composition of interstitial fluid. Clin Chem. 1995;41:1522-1525.

71. Handwerker SM, Altura BT, Altura BM. Serum ionized magnesium and other electrolytes in the antenatal period of human pregnancy. $J$ Am Coll Nutr. 1996;15(1):36-43.

72. Scott VL, DeWolf AM, Kang Y, et al. Ionized hypomagnesemia in patients undergoing orthotopic liver transplantation: A complication of citrate intoxication. Liver Transpl and Surg. 1996;2(5):343-347.

73. Fogh Andersen N, Altura BM, Altura BT, et al. Changes in plasma ionized calcium and magnesium in blood donors after donation of $450 \mathrm{ml}$ blood. Scand J Clin Lab Invest. 1996;56(suppl 224):245-250.

74. Altura BM, Altura BT. Role of magnesium in patho-physiologica processes and the clinical utility of magnesium ion selective electrodes. Scand J Clin Lab Invest. 1996;56(suppl 224):211-234.

75. Altura BM, Altura BT. Magnesium metabolism, atherogenesis and cardiovascular pathobiology. In: Advances in Magnesium Research, Smetana R. John Libbey Co., London, 1997;28-38.

76. Altura BT, Memon ZS, Zhang A, et al. Low levels of serum ionized magnesium are found in stroke patients early after stroke which results in rapid elevation in cytosolic free calcium and spasm in cerebral vascular muscle cells. Neurosci Lett. 1997;230(1):37-40.
77. Altura BT, Zhang A, Altura BM. Vascular diseases and ionized magnesium. In: Theophanides T, AnastassopoulosI, editors. Magnesium: Current Status and New Developments, Kluwer Amsterdam. 1997;397405 .

78. Altura BM, Altura BT. Mg and Atherogenesis. In: Theophanides T, Anastassopoulos I, editors. Magnesium: Current Status and New Developments, Kluwer, Amsterdam, 1997;385-396.

79. Resnick LM, Bardicef O, Altura BT, et al. Serum ionized magnesium: Relation to blood pressure and racial factors. Am J Hypertens. 1997;10(12 pt1):1420-1424.

80. Altura BM, Altura BT. Association of alcohol in brain injury, headaches, and stroke with brain-tissue and serum levels of ionized magnesium: A review of recent findings. Alcohol. 1999;19(2):119-130.

81. Muneyyrici Delale O, Nacharaju VL, Altura BM, et al. Serum ionized magnesium and calcium and sex hormones in healthy young men: importance of progesterone level. Fertil Steril. 1999;72(5):817-822.

82. DjurhuusMS, Henriksen JE, KlitgaardNAH, et al. Effect of moderate improvement in metabolic control on magnesium and lipid concentrations in patients with type 1 diabetes. Diabetes Care. 1999;22(4):546-554.

83. Muneyyrici Delale O, Nacharaju VL, Dailloul M, et al. Serum ionized magnesium and calcium in women after menopause: inverse relationship of estrogen with ionized magnesium. Fertil Steril. 1999;71(5):869-873.

84. Muneyyrici Delale O, Nacharaju VL, Jalou S, et al. Divalent cations in PCOS: implications in cardiovascular disease. Gynecol Endocrinol. 2001;15(3):198-201.

85. Djurhuus MS, Klitgaard NAH, Pedersen KK, et al. Magnesium reduces insulin-stimulated glucose uptake and serum lipid concentrations in type 1 diabetes. Metabol. 2001;50(12):1409-1417.

86. Djurhuus MS, Vaag A, Altura BM, et al. Skeletal muscle magnesium content in identical twins discordant for type 2 diabetes. Diabetes Metabol. 2002;28(3):201-207.

87. Altura RA, Wang WC, Altura BM, et al. Hydroxyurea therapy associated with declining serum levels of magnesium in children with sickle cell anemia. $J$ Pediatr. 2002;140(5):565-569.

88. Zetabchi S, Sinert R, Rinnert C, et al. Serum ionized magnesium levels and calcium levels in adult patients with sickle cell anemia. Scand J Clin Lab Invest. 2004;77(3):215-222.

89. Sinert R, Zetabchi S, Desai S, et al. Serum ionized magnesium and calcium levels in adult patients with seizures. Scand J Clin Lab Invest. 2007;67(3):317-326.

90. Apostol A, Apostol R, Ali E, et al. Cerebral spinal fluid and serum ionized magnesium and calcium levels in preeclamptic women during administration of magnesium sulfate. Fertil Steril. 2009;94(1):276-282.

91. Altura BM, Li W, Zhang A, et al. The expression of platelet-activating factor is induced by low extracellular $\mathrm{Mg}^{2+}$ in aortic, cerebral and neonatal coronary vascular smooth muscle; cross talk with ceramide production, NF-kB and proto-oncogenes: Possible links in atherogenesis and sudden cardiac death in children and infants, and aging, Hypothesis, review and viewpoint. Int J Cardiol Res. 2016;3(1):47-62.

92. Altura BM, Altura BT. Importance of ionized magnesium measurements in physiology and medicine and the need for ion-selective electrodes. $J$ Clin Case Studies. 2016;1(2).

93. Altura BM, Zhang A, Shah NC, et al. Euphoria from drinking alcoholic beverages may be due to reversible constriction of cerebral blood vessels: potential roles of unrecognized ionized hypomagnesemia, release of ceramides and platelet-activating factor. Clinical Res and Trials. 2016;2(6):242-245. 
94. Altura BM, Shah NC, Shah GJ, et al. Why do chemotherapeutic drugs and radiation induce cardiomyopathy and cardiac failure in cancer patients: Is this a consequence of unrecognized hypomagnesemia and release of ceramides and platelet-activating factor? SciFed J Emerg Med. 2017;1(1):1-9.

95. Altura BM, Shah NC, Shah GJ, et al. Is the high frequency of postoperative atrial fibrillation after cardiac and lung surgeries related to hypomagnesemia and release of ceramides and platelet-activating factor? Clinics in Surgery. 2016;1:1-3.

96. Altura BM, Li W, Zhang A, et al. Sudden cardiac death in infants, children and young adults: possible roles of dietary magnesium intake and generation of platelet-activating factor in coronary arteries. $J$ Heart Health. 2016;2(2).

97. Altura BM, Burack J, Tranbaugh RF, et al. Why is cardiac morbidity and mortality greater around Christmas, New Year's and Monday mornings and in the morning hours: Potential roles of unrecognized ionized hypomagnesemia and release of ceramides. Cardiovasc Ther: Open Access. 2017;2(2);1000118.

98. Altura BM, Gebrewold A, Carella A, et al. Stroke: A real danger of the therapeutic use of psychedelic drugs and the role of magnesium depletion. EC Pharmacol and Toxicol. 2018;S1:18-23.

99. Altura BM, Gebrewold A, Carella A, et al. Increased risk of stroke using marijuana-cannabis products: evidence for dangerous effects on brain circulation and the unrecognized roles of magnesium. Drugs and Alcohol Addiction. 2018;1(1):001-006.

100. Altura BM, Shah NC, Shah GJ, et al. Magnesium deficiency, sphingolipids, and telomerase: Relevance to atherogenesis, cardiovascular diseases, and aging. In: Preedy VR, Patel VB, editors. Handbook of Famine, Starvation, and Nutrient Deprivation, Springer International Publishing AG, Berlin 2018.

101. Altura BM, Carella A, Gebrewold A, et al. Why there is an increased number of deaths from heroin mixed with fentanyl in the USA: Potential roles of unrecognized hypomagnesemia and elevated levels of ceramide and platelet-activating factor particularly in brain stem area and potential relationship to euphoria and hallucinations. Acta Sci Pharmaceutical Sciences. 2019;3(8):55-62.

102. Altura BM, Shah NC, Shah GJ, et al. Emerging role of epigenetics in cardiovascular diseases: Importance of ionized magnesium. Int $J \mathrm{Mol}$ Biol:Open Access. 2019;4(6):202-204.

103. Altura BM, Gebrewold A, Carella A, et al. HDFx and magnesium in combination ameliorates experimental pulmonary hypertension: relevance to treatment of pulmonary hypertension in humans and newborns and the roles of hypomagnesemia, ceramides and platelet-activating factor. $E C$ Cardiology. 2020;7(2):1-10.

104. Altura BM, Gebrewold A, Carella A, et al. Cell death signaling mechanisms in cardiac failure caused by magnesium deficiency: relationship to etiology of atherogenesis and sudden death ischemic heart disease. Int J Mol Biol: Open Access. 2020;5(2):67-71.

105. Altura BM, Gebrewold A, Carella A, et al. Why it is difficult to treat and prevent drug-resistant hypertension and elevated pulse pressure: the unrecognized roles of hypomagnesemia, nitric oxide, ceramides, platelet-activating factor, and epigenesis. Int $J$ Mol Biol: Open Access. 2020;5(2):53-58.

106. Altura BM, Carella A, Gebrewold A, et al. Why there is an increased risk of cardiac failure, widening of pulse pressure and hemorrhagic stroke in type 2 diabetics over age 60: Roles of unrecognized hypomagnesemia and epigenetics coupled with increased levels of ceramides, cytokines, ROS, 4-HNE and platelet-activating factor. J Clinical Case Studies. 2020;5(2).

107. Barbagallo M, Gupta RK, Dominguez LJ, et al. Cellular ionic alteration with age: relation to hypertension and diabetes. J Am Geriatr Soc. 2000;48(9):1111-1116.
108. Barbagallo M, Belvedere M, Dominguez LJ. Magnesium homeostasis in aging. Magnes Res. 2009;22(4):235-246.

109. Ross R. Atherosclerosis-An inflammatory disease. New Engl J Med 1999;340(2):115-126.

110. Barnes PJ, Karin M. Nuclear factor-kB-A pivotal transcription factor in chronic inflammatory disease. New Engl J Med. 1997;336(15):1066-1071.

111. Bauerle PA, Baltimore D. NF-kB: ten years later. Cell. 1996;87(1):13-20.

112. Ransone LJ, Verna IM. Nuclear proto-oncogenes fos and jun. Ann Rev Cell Biol. 1990;6:539-557.

113. Hayden MS, Ghosh S. NF-kB in immunology. Cell Res. 2011;21(2):233-244.

114. Altura BM, Kostellow AB, Zhang A, et al. Expression of the nuclear factor-kB and proto-oncogenes c-fos and c-jun are induced by low extracellular $\mathrm{Mg}^{2+}$ in aortic and cerebral vascular smooth muscle cells: possible links to hypertension, atherogenesis, and stroke. Am J Hypertens. 2003;16(9):701-707.

115. Menendez D, Inga A, Resnick MA. The expanding universe of p53 targets. Nat Rev Cancer Res. 2007;9:724-737.

116. Mercer J, Mahmoudi M, Bennett M. DNA damage, p53,apoptosis and vascular disease. Mutat Res. 2009;621:75-86.

117. Meek DW. Tumor suppression by p53: a role for the DNA damage response? Nat Rev Cancer. 2009;9:714-723.

118. Altura BM, Shah NC, Li Z, et al. Short-term magnesium deficiency upregulates sphingomyelin synthase and p53 in cardiovascular tissues and cells: relevance to de novo synthesis of ceramide. Am J Physiol Heart Circ Physiol. 2010;299(6):H2046-H2055.

119. Altura BM, Shah NC, Jiang X-C, et al. Short-term magnesium deficiency results in decreased levels of serum sphingomyelin, lipid peroxidation, and apoptosis in cardiovascular tissues. Am J Physiol Heart Circ Physiology. 2009;297(1):H86-H92.

120. Altura BM, Shah NC, Shah GJ, et al. Regulated RIPK3 necroptosis is produced in cardiovascular tissues and cells in dietary magnesium deficiency: Roles of cytokines and their potential importance in inflammation andatherogenesis. J Med Surg Pathol. 2017;2:e104.

121. Altura BM, Gebrewold A, Carella A, et al. Regulated ferroptosis cell death is produced in cardiovascular tissues and cells in dietary magnesium deficiency: Initiation of roles of glutathione, mitochondrial alterations and lipid peroxidation in inflammation and atherogenesis. EC Pharmacol\&Toxicol. 2018;6:535-541.

122. Altura BM, Gebrewold A, Carella A, et al. Regulated pyroptosis is produced in cardiovascular tissues and cells in dietary magnesium deficiency: Cross-talk with cytokines, PAF, telomerases and aging. EC Pharmacol\& Toxicol. 2019;7:25-30.

123. Altura BM, Shah NC, Shah GJ, et al. Magnesium deficiency results in oxidation and fragmentation of DNA, downregulation of telomerase activity, and ceramide release in cardiovascular tissues and cells: potential relationship to atherogenesis, cardiovascular diseases and aging. Int $J$ Diabetol Vasc Dis Res. 2016;4:1-5.

124. Azzia A, Boscoboinik D, Hensey C. The protein kinase C family. Eur J Biochem. 1992;208:547-557.

125. Chauhan VPS, Chauhan A, Deshmukh DS, et al. Lipid activators of protein kinase C. Life Sci. 1990;47:981-986.

126. Mellor H, Parker PJ. The extended protein kinase C superfamily. Biochem J. 1998;332:281-292.

127. Mochly Rosen D. Localization of protein kinasesby anchoring proteins: a theme in signal transduction. Science. 1995;268():247-251.

Citation: Altura BM, Shah NC, Shah GJ, et al.Why typos in DNA may help to fuel atherogenesis and inflammation prior to heart attacks, ischemic heart disease, and sudden-death ischemic heart disease: roles of unrecognized ionized hypomagnesemia and epigenetics. Int J Mol Biol Open Access. $2020 ; 5$ (3): I I - I I7. DOI: I0.15406/ijmboa.2020.05.00137 
128. Newton AC, KoshlandDE. Phosphatidylserine affects specificity of protein kinase $\mathrm{C}$ substrate phosphorylation and autophosphorylation. Biochemistry. 1990;29:6656-6661.

129. Otte AP, Kramer IM, Durston AJ. Protein kinase C and the regulation of the local competence of xenopus ectoderm. Science. 1991;251:570-573.

130. Yang ZW, Wang J, Altura BT, et al. Extracellular magnesium deficiency induces contraction of arterial muscle: role of $\mathrm{PI}_{3}$ kinases and MAPK 134 signaling pathways. Pflugers Arch-EurJPhysiol. 1999;439:240-247.

131. Yang ZW, Wang J, Zheng T, et al. Low $\left[\mathrm{Mg}^{2+}\right]_{0}$ induces contractions of cerebral arteries: roles of tyrosine and mitogen -activated protein kinases. Am J Physiol Heart Circ Physiol. 2000;279:H185-H194.
32. Yang ZW, Altura BT, Altura BM. Low extracellular $\mathrm{Mg}^{2+}$ contraction of arterial muscle: role of protein kinase $\mathrm{C}$ and protein tyrosine phosphorylation. Eur J Pharmacol. 1999;378:273-281.

33. Yang ZW, Wang J, Zheng $\mathrm{T}$, et al. Low extracellular $\mathrm{Mg}^{2+}$ induces contraction and $\left[\mathrm{Ca}^{2+}\right]_{1}$ elevation in cerebral arteries :roles of $\mathrm{Ca}^{2+}, \mathrm{PKC}$ and $\mathrm{PI}_{3}$. Am J Physiol Heart Circ Physiol. 2000;48(6):2898-2907.

134. Altura BM, Shah NC, Shah GJ, et al. Short-term Mg deficiency upregulates protein kinase $\mathrm{C}$ isoforms in cardiovascular tissues and cells; relation to NF-kB, cytokines, ceramide salvage sphingolipid pathway and PKC-zeta: hypothesis and review. Int J Clin Exp Med. 2014;7(1):1-21. 